Vol 2. No 1. Januari 2022 P-ISSN : 2774-8022, e-ISSN : 2774-5791

\title{
PENGGUNAAN APLIKASI PIXTON UNTUK MENINGKATKAN MINAT MENULIS PADA MATERI TEKS CERITA SEJARAH KELAS XII
}

\author{
MUFARROCHAH \\ MAN 3 Blitar \\ Email: mufawawa@yahoo.co.id
}

\begin{abstract}
ABSTRAK
Menulis bukanlah hal yang mudah. Apalagi bagi pemula atau yang sama sekali belum pernah menulis. Kegiatan menulis menjadi kegiatan yang membosankan, tidak menyenangkan. Menulis menjadi hal yang menakutkan. Berat sekali untuk melakukannya. Tidak tahu harus mulai dari mana. Berbagai permasalahan ini dapat dipecahkan dengan perkembangan teknologi yang semakin maju. Teknologi diciptakan untuk dapat membantu dan mempermudah manusia dalam mengerjakan sesuatu. Dalam bidang pendidikan, beragam aplikasi bisa digunakan untuk menunjang kegiatan belajar mengajar, salah satunya adalah aplikasi Pixton. Pixton adalah situs web yang memungkinkan peserta didik membuat komik online tanpa memasang apa pun di komputer. Tujuan yang ingin dicapai dalam penelitian ini untuk (1) mendeskripsikan peningkatan minat menulis cerita melalui aplikasi Pixton. (2) Mendeskripsikan hasil menulis cerita melalui aplikasi Pixton. Penelitian ini menggunakan pendekatan kualitatif dengan analisis deskriptif. Teknik pengumpulan data dalam penelitian ini menggunakan quesioner. Metode penskalaan atas pernyataan sikap menggunakan skala likert dengan lima alternatif jawaban. Hasil penelitian 91,4\% responden yang menjawab sangat setuju dan setuju bahwa aplikasi Pixton menarik bila digunakan untuk menulis cerita. Sebanyak $80 \%$ responden menyatakan aplikasi Pixton tidak membuat responden bosan dalam menyelesaikan sebuah cerita. Sebanyak 94,3\% menyatakan menulis cerita dengan menggunakan aplikasi Pixton lebih menarik dari pada menulis cerita di selembar kertas. Sebanyak $94,3 \%$ responden menyatakan aplikasi Pixton dapat meningkatkan kreativitas dan minat menulis cerita. Hasil menulis cerita melalui Aplikasi Pixton dengan nilai rata-rata menyusun teks cerita 83,8 .
\end{abstract}

Kata Kunci: minat menulis cerita, aplikasi Pixton

\begin{abstract}
Writing is not an easy thing. Especially for beginners or those who have never written. Writing activities become boring activities, not fun. Writing is a scary thing. It's very hard to do. Sometimes we don't know where to start. These problems can be solved with the development of increasingly advanced technology. Technology was created to be able to help and make it easier for humans to do things. In the field of education, various applications can be used to support teaching and learning activities, one of which is the Pixton application. Pixton is a website that allows students to create comics online without installing anything on their computer. The objectives to be achieved in this study are to (1) describe the increase in interest in writing stories through the Pixton application. (2) Describe the results of writing stories through the Pixton application. This study uses a qualitative approach with descriptive analysis. Data collection techniques in this study uses a questionnaire. The method of scaling the attitude statement uses a Likert scale with five alternative answers. The results of the study were $91.4 \%$ of respondents who answered strongly agree and agree that the Pixton application is interesting when used to write stories. $80 \%$ of respondents stated that the Pixton application did not make respondents bored in completing a story. $94.3 \%$ stated that writing stories using the Pixton application was more interesting than writing stories on a piece of paper. $94.3 \%$ of respondents stated that the Pixton application can increase creativity and interest in writing stories. The results of writing stories through the Pixton Application with an average value of compiling story texts are 83.8.
\end{abstract}

Keywords: story writing interest, Pixton app. 


\section{PENDAHULUAN}

Keterampilan berbahasa meliputi empat hal yaitu menyimak, berbicara, membaca, dan menulis. Keterampilan ini menurut sifatnya terbagi dua. Pertama bersifat reseptif yaitu menerima atau memahami pesan diutarakan pembicara atau penulis. Keterampilan berbahasa yang tergolong reseptif yaitu menyimak dan membaca. Kedua bersifat produktif yaitu menghasilkan pembicaraan atau tulisan. Keterampilan berbahasa yang tergolong produktif ialah berbicara dan menulis.

Keterampilan menulis merupakan keterampilan berbahasa yang paling tinggi tingkatannya dibandingkan keterampilan berbicara, keterampilan membaca, dan keterampilan menyimak. Hal ini dikarenakan tahapan pemerolehan bahasa keterampilan menulis dilakukan pada tahapan terakhir setelah pemerolehan keterampilan menyimak berbicara dan membaca (Jamhari dan Siregar, 2019).

Dalam dunia pendidikan, kegiatan menulis sangat penting dalam melatih (anak didik) menuangkan dan mengembangkan ide, pengalaman, serta kemampuan berfikir nya ke dalam bentuk tulisan (Munurah, 2015). Menulis adalah kegiatan yang kompleks karena dengan menulis terdapat aktivitas menyusun dan mengorganisasikan isi tulisan serta menuangkannya dalam ragam bahasa tulis (Dalman, 2016).

Paradigma pembelajaran bahasa Indonesia dalam Kurikulum 2013 diorientasikan pada pembelajaran berbasis teks. Macam-macam bentuk kegiatan menulis dalam pembelajaran Bahasa Indonesia teks deskripsi, narasi, prosedur, laporan hasil observasi, surat pribadi dan surat dinas, puisi rakyat, dan teks fabel atau legenda, teks berita, teks iklan, slogan, atau poster, teks eksposisi, puisi, eksplanasi, ulasan, persuasi, dan teks drama, teks laporan percobaan, pidato persuasif, cerpen, teks tanggapan, teks diskusi, dan teks cerita inspiratif.

Salah satu kegiatan menulis dalam pembelajaran Bahasa Indonesia adalah menulis cerita pendek. Menulis termasuk aspek kegiatan berbahasa yang membutuhkan pemikiran khusus. Peserta didik di pendidikan dasar dan menengah, mahasiswa di pendidikan tinggi, dan bahkan orang-orang yang sudah menamatkan perguruan tinggi pun mengeluhkan sulitnya menulis. Akibatnya menjadi opini umum bahwa menulis itu kegiatan yang sulit.

Banyak sekali masalah yang dihadapi dalam membuat sebuah karya. Salah satunya adalah produktivitas. Produktivitas secara umum adalah kemampuan setiap orang dalam menghasilkan sesuatu yang diinginkan dengan cara memanfaatkan sumber daya secara efektif dan juga efisien. Sering kali memiliki banyak ide, tetapi untuk menuangkannya dalam tulisan mengalami kesulitan.

Menulis bukanlah hal yang mudah. Apalagi bagi pemula atau yang sama sekali belum pernah menulis. Kegiatan menulis menjadi kegiatan yang membosankan, tidak menyenangkan. Menulis menjadi hal yang menakutkan. Berat sekali untuk melakukannya. Tidak tahu harus mulai dari mana. Apa yang akan dibahas. Layak tidak cerita yang dibahas dan lain-lain. Akhirnya tidak jadi menulis.

Masalah lain yang dihadapi penulis pemula adalah tidak percaya diri. Hal ini disebabkan karena penulis menganggap dirinya tidak memiliki kemampuan menulis. Padahal seorang penulis profesional berangkat dari seorang penulis pemula yang mungkin memiliki banyak kekurangan.

Selain itu, pada pembelajaran menulis cerita, guru memberikan tema khusus. Pembatasan tema ini menyebabkan siswa terbatasi dalam berkreativitas. Siswa akan kesulitan dalam mengembangkan gagasan dan pikirannya ke dalam cerita. Akibatnya, siswa kurang bersemangat dalam kegiatan pembelajaran (Padmi, 2017).

Keterampilan menyusun cerita dalam pembelajaran merupakan keterampilan yang butuh kemampuan khusus. Yakni kemampuan individu dalam memunculkan gagasan, pikiran, dan perasaan untuk menjadi sebuah karya. Dalam pengajaran sastra terutama keterampilan menulis cerita merupakan kegiatan yang masih kurang diminati siswa. Salah satu hal yang menjadi faktor pemicunya adalah guru kurang memotivasi siswa, guru kurang meningkatkan model pembelajaran yang menarik yang menjadikan siswa kurang bersemangat dalam menulis 
cerita (Mastini, 2016).

Berbagai permasalahan ini dapat dipecahkan dengan perkembangan teknologi yang semakin maju. Teknologi diciptakan untuk dapat membantu dan mempermudah manusia dalam mengerjakan sesuatu. Dalam bidang pendidikan, beragam aplikasi bisa digunakan untuk menunjang kegiatan belajar mengajar, salah satunya adalah aplikasi Pixton. Pixton adalah situs web yang memungkinkan peserta didik membuat komik online tanpa memasang apa pun di komputer. Platform ini memberi kemudahan untuk memilih karakter, skenario, dan menambahkan balon percakapan untuk membuat cerita dengan mudah.

Dengan adanya penelitian ini diharapkan menjadi solusi dalam kegiatan pembelajaran khususnya dalam pembelajaran menulis cerita. Oleh karena itu, judul karya tulis ini yaitu "Penggunaan Aplikasi Pixton untuk Meningkatkan Minat Menulis pada Materi Teks Cerita Sejarah Kelas XII”.

\section{METODE PENELITIAN}

Penelitian ini menggunakan pendekatan kualitatif dengan analisis deskriptif. Yaitu penelitian yang menggambarkan keadaan yang sebenarnya dari kenyataan objek yang diteliti. Dalam Penelitian kualitatif kehadiran peneliti sangatlah penting dan utama. Hal ini dikarenakan peneliti merupakan alat pengumpul data utama. Peneliti merupakan instrumen kunci utama dalam mengungkapkan makna dan sekaligus sebagai alat pengumpul data

Penelitian dilakukan di MAN 3 Blitar. MAN 3 Blitar terletak di jalan Pondok Pesantren Al Kamal Kunir, Wonodadi, Blitar, Jawa Timur. Waktu penelitian Oktober 2021 terhitung mulai tanggal 6-27 Oktober 2021.

Sumber data dalam penelitian ini adalah item-item pertanyaan dalam bentuk kuesioner. Jawaban responden atas pertanyaan kuesioner menjadi data pokok untuk mengetahui peningkatan minat menulis cerita melalui Aplikasi Pixton dalam kegiatan belajar mengajar di MAN 3 Blitar. Populasi dari penelitian ini yaitu siswa MAN 3 Blitar kelas XII dengan sampel kelas XII KAGM 1 berjumlah 35 siswa.

Teknik pengumpulan data dalam penelitian ini menggunakan kuesioner. Berupa pertanyaan tertulis yang bersifat tertutup dengan pilihan yang sudah disediakan. Pertanyaan yang diajukan mengenai peningkatan minat menulis cerita melalui Aplikasi Pixton. Yang menjadi responden dalam penelitian ini yaitu siswa-siswi kelas 12 KAGM 1 MAN 3 Blitar. Metode penskalaan atas pernyataan sikap menggunakan skala Likert dengan lima alternatif jawaban yaitu sangat setuju, setuju, ragu-ragu, tidak setuju, dan sangat tidak setuju. Sedangkan untuk mengetahui kemampuan hasil menulis cerita menggunakan teknik penugasan (tugas menulis cerita).

Data yang sudah terkumpul selanjutnya diolah dan dianalisis dengan menggunakan tahapan penyuntingan (editing). Tahapan ini merupakan proses memeriksa dan mengecek datadata yang sesuai dengan rumusan permasalahan penelitian. Tahap kedua yaitu pengkodean (coding). Tahap ini data ditandai dengan simbol atau tanda tertentu sebagai bahan analisis. Tahap ketiga yaitu tabulasi (tabulating). Tahap tabulasi ini merupakan tahap yang mengharuskan peneliti untuk menyusun atau menyajikan data-data tersebut disesuaikan dengan permasalahan penelitian.

Data yang diperoleh di lapangan kemudian diklasifikasikan, diolah, dan dianalisis secara deskriptif kualitatif yaitu suatu proses pemecahan masalah yang menggambarkan obyek yang diteliti berdasarkan data yang diperoleh pada saat meneliti yang kemudian dijadikan sebuah kesimpulan.

\section{HASIL DAN PEMBAHASAN}

Hasil dan pembahasaan "Peningkatan Minat Menulis Cerita melalui Aplikasi Pixton" sebagai berikut.

\section{Hasil}

\section{Tingkat Kemenarikan Aplikasi Pixton untuk Peningkatan Minat Menulis Cerita}


Vol 2. No 1. Januari 2022 P-ISSN : 2774-8022, e-ISSN : 2774-5791

Angket yang telah disusun melalui Google Form lalu disebarkan kepada 35 anggota kelas XII KAGM 1 MAN 3 Blitar mengenai peningkatan minat menulis cerita melalui aplikasi Pixton. Setelah itu, data diedit dan ditabulasikan dalam bentuk persentase. Hasilnya dideskripsikan sebagai berikut.

Tabel 1 Siswa pernah menulis cerita pendek

\begin{tabular}{|l|c|c|}
\hline \multicolumn{1}{|c|}{ JAWABAN } & FREKUENSI & PERSENTASE \\
\hline Sangat setuju & 21 & $60 \%$ \\
\hline Setuju & 13 & $37,1 \%$ \\
\hline Ragu-ragu & 1 & $2,9 \%$ \\
\hline Tidak setuju & - & - \\
\hline Sangat tidak setuju & - & - \\
\hline JUMLAH & 35 & $100 \%$ \\
\hline
\end{tabular}

Berdasarkan data tabel 1 di atas dapat diketahui bahwa responden sudah pernah menulis cerita pendek. Yang menjawab sangat setuju sebanyak 21 siswa (60\%). Yang menjawab setuju sebanyak 13 siswa $(37,1 \%)$ dan yang menjawab ragu-ragu $1(2,9 \%)$.

Tabel 2 Siswa berkeinginan menjadi penulis cerita meskipun dalam lingkup sekolah

\begin{tabular}{|l|c|c|}
\hline \multicolumn{1}{|c|}{ JAWABAN } & FREKUENSI & PERSENTASE \\
\hline Sangat setuju & 14 & $40 \%$ \\
\hline Setuju & 11 & $31,4 \%$ \\
\hline Ragu-ragu & 7 & $20 \%$ \\
\hline Tidak setuju & 3 & $8,6 \%$ \\
\hline Sangat tidak setuju & - & - \\
\hline JUMLAH & 35 & $100 \%$ \\
\hline
\end{tabular}

Berdasarkan data tabel 2 di atas dapat diketahui bahwa responden berkeinginan menjadi penulis cerita meskipun dalam lingkup sekolah. Yang menjawab sangat setuju sebanyak 14 siswa (40\%). Yang menjawab setuju sebanyak 11 siswa (31,4\%), yang menjawab ragu-ragu 7 siswa $(20 \%)$ dan yang menjawab tidak setuju sebanyak 3 siswa $(8,6 \%)$.

Tabel 3 Siswa sudah pernah menggunakan aplikasi Pixton

\begin{tabular}{|l|c|c|}
\hline \multicolumn{1}{|c|}{ JAWABAN } & FREKUENSI & PERSENTASE \\
\hline Sangat setuju & 8 & $22,9 \%$ \\
\hline Setuju & 8 & $22,9 \%$ \\
\hline Ragu-ragu & 5 & $5,7 \%$ \\
\hline Tidak setuju & 17 & $48,6 \%$ \\
\hline Sangat tidak setuju & - & - \\
\hline JUMLAH & 35 & $100 \%$ \\
\hline
\end{tabular}


Berdasarkan data tabel 3 di atas dapat diketahui bahwa responden yang sudah pernah menggunakan aplikasi Pixton. Yang menjawab sangat setuju sebanyak 8 siswa (22,9\%). Yang menjawab setuju sebanyak 8 siswa $(22,9 \%)$, yang menjawab ragu-ragu 5 siswa $(5,7 \%)$ dan yang menjawab tidak setuju sebanyak 17 siswa $(48,6 \%)$.

Tabel 4 Aplikasi Pixton mudah digunakan meskipun bagi pemula

\begin{tabular}{|l|c|c|}
\hline \multicolumn{1}{|c|}{ JAWABAN } & FREKUENSI & PERSENTASE \\
\hline Sangat setuju & 22 & $62,9 \%$ \\
\hline Setuju & 5 & $14,3 \%$ \\
\hline Ragu-ragu & 7 & $20 \%$ \\
\hline Tidak setuju & 1 & $2,9 \%$ \\
\hline Sangat tidak setuju & - & - \\
\hline JUMLAH & 35 & $100 \%$ \\
\hline
\end{tabular}

Berdasarkan data tabel 4 di atas dapat diketahui bahwa responden yang menyatakan bahwa aplikasi Pixton mudah digunakan meskipun bagi pemula. Yang menjawab sangat setuju sebanyak 22 siswa (62,9\%). Yang menjawab setuju sebanyak 5 siswa $(14,3 \%)$, yang menjawab ragu-ragu 7 siswa (20\%) dan yang menjawab tidak setuju sebanyak 1 siswa $(2,9 \%)$.

Tabel 5 Aplikasi Pixton sangat menarik bila digunakan untuk menulis cerita

\begin{tabular}{|l|c|c|}
\hline \multicolumn{1}{|c|}{ JAWABAN } & FREKUENSI & PERSENTASE \\
\hline Sangat setuju & 21 & $60 \%$ \\
\hline Setuju & 11 & $31,4 \%$ \\
\hline Ragu-ragu & 3 & $8,6 \%$ \\
\hline Tidak setuju & - & - \\
\hline Sangat tidak setuju & - & - \\
\hline JUMLAH & 35 & $100 \%$ \\
\hline
\end{tabular}

Berdasarkan data tabel 5 di atas dapat diketahui bahwa responden yang menyatakan bahwa aplikasi Pixton sangat menarik bila digunakan untuk menulis cerita. Yang menjawab sangat setuju sebanyak 21 siswa $(60 \%)$. Yang menjawab setuju sebanyak 11 siswa $(31,4 \%)$, yang menjawab ragu-ragu 3 siswa $(8,6 \%)$.

Tabel 6 Siswa tidak merasa kesulitan menggunakan aplikasi Pixton

\begin{tabular}{|l|c|c|}
\hline \multicolumn{1}{|c|}{ JAWABAN } & FREKUENSI & PERSENTASE \\
\hline Sangat setuju & 15 & $42,9 \%$ \\
\hline Setuju & 13 & $37,1 \%$ \\
\hline Ragu-ragu & 2 & $5,7 \%$ \\
\hline Tidak setuju & 5 & $14,3 \%$ \\
\hline Sangat tidak setuju & - & - \\
\hline
\end{tabular}


Vol 2. No 1. Januari 2022 P-ISSN : 2774-8022, e-ISSN : 2774-5791

\begin{tabular}{|l|c|c|}
\hline JUMLAH & 35 & $100 \%$ \\
\hline
\end{tabular}

Berdasarkan data tabel 6 di atas dapat diketahui bahwa responden yang menyatakan bahwa tidak merasa kesulitan menggunakan aplikasi Pixton. Yang menjawab sangat setuju sebanyak 15 siswa (42,9\%). Yang menjawab setuju sebanyak 13 siswa $(37,1 \%)$, yang menjawab ragu-ragu 2 siswa $(5,7 \%)$ dan yang menjawab tidak setuju sebanyak 5 siswa $(14,3 \%)$.

Tabel 7 Siswa terbantu dengan aplikasi Pixton dalam tugas menulis cerita di sekolah

\begin{tabular}{|l|c|c|}
\hline \multicolumn{1}{|c|}{ JAWABAN } & FREKUENSI & PERSENTASE \\
\hline Sangat setuju & 19 & $54,3 \%$ \\
\hline Setuju & 12 & $34,3 \%$ \\
\hline Ragu-ragu & 3 & $8,6 \%$ \\
\hline Tidak setuju & 1 & $2,9 \%$ \\
\hline Sangat tidak setuju & - & - \\
\hline JUMLAH & 35 & $100 \%$ \\
\hline
\end{tabular}

Berdasarkan data tabel $7 \mathrm{di}$ atas dapat diketahui bahwa responden yang menyatakan terbantu dengan aplikasi Pixton dalam tugas menulis cerita di sekolah. Yang menjawab sangat setuju sebanyak 19 siswa $(54,3 \%)$. Yang menjawab setuju sebanyak 12 siswa $(34,3 \%)$, yang menjawab ragu-ragu 3 siswa $(8,6 \%)$ dan yang menjawab tidak setuju sebanyak 1 siswa $(2,9 \%)$.

Tabel 8 Siswa bisa menyelesaikan sebuah cerita dengan menggunakan aplikasi Pixton

\begin{tabular}{|l|c|c|}
\hline \multicolumn{1}{|c|}{ JAWABAN } & FREKUENSI & PERSENTASE \\
\hline Sangat setuju & 18 & $51,4 \%$ \\
\hline Setuju & 12 & $34,3 \%$ \\
\hline Ragu-ragu & 4 & $11,4 \%$ \\
\hline Tidak setuju & 1 & $2,9 \%$ \\
\hline Sangat tidak setuju & - & - \\
\hline JUMLAH & 35 & $100 \%$ \\
\hline
\end{tabular}

Berdasarkan data tabel 8 di atas dapat diketahui bahwa responden yang menyatakan bisa menyelesaikan sebuah cerita dengan menggunakan aplikasi Pixton. Yang menjawab sangat setuju sebanyak 18 siswa (51,4\%). Yang menjawab setuju sebanyak 12 siswa (34,3\%), yang menjawab ragu-ragu 4 siswa $(11,4 \%)$ dan yang menjawab tidak setuju sebanyak 1 siswa $(2,9 \%)$.

Tabel 9 Siswa bisa mengungkapkan ide-ide cerita ketika menggunakan aplikasi Pixton

\begin{tabular}{|l|c|c|}
\hline \multicolumn{1}{|c|}{ JAWABAN } & FREKUENSI & PERSENTASE \\
\hline Sangat setuju & 18 & $51,4 \%$ \\
\hline Setuju & 10 & $28,6 \%$ \\
\hline Ragu-ragu & 5 & $14,3 \%$ \\
\hline Tidak setuju & 2 & $5,7 \%$ \\
\hline
\end{tabular}


Vol 2. No 1. Januari 2022 P-ISSN : 2774-8022, e-ISSN : 2774-5791

\begin{tabular}{|l|c|c|}
\hline Sangat tidak setuju & - & - \\
\hline JUMLAH & 35 & $100 \%$ \\
\hline
\end{tabular}

Berdasarkan data tabel 9 di atas dapat diketahui bahwa responden yang menyatakan bisa mengungkapkan ide-ide cerita ketika menggunakan aplikasi Pixton. Yang menjawab sangat setuju sebanyak 18 siswa (51,4\%). Yang menjawab setuju sebanyak 10 siswa $(28,6 \%)$, yang menjawab ragu-ragu 5 siswa $(14,3 \%)$ dan yang menjawab tidak setuju sebanyak 2 siswa $(5,7 \%)$.

Tabel 10 Siswa merasa tidak bosan untuk menyelesaikan sebuah cerita dengan menggunakan aplikasi Pixton

\begin{tabular}{|l|c|c|}
\hline \multicolumn{1}{|c|}{ JAWABAN } & FREKUENSI & PERSENTASE \\
\hline Sangat setuju & 19 & $54,3 \%$ \\
\hline Setuju & 9 & $25,7 \%$ \\
\hline Ragu-ragu & 5 & $14,3 \%$ \\
\hline Tidak setuju & 2 & $5,7 \%$ \\
\hline Sangat tidak setuju & - & - \\
\hline JUMLAH & 35 & $100 \%$ \\
\hline
\end{tabular}

Berdasarkan data tabel 10 di atas dapat diketahui bahwa responden yang menyatakan merasa tidak bosan untuk menyelesaikan sebuah cerita dengan menggunakan aplikasi Pixton. Yang menjawab sangat setuju sebanyak 19 siswa (54,3\%). Yang menjawab setuju sebanyak 9 siswa $(25,7 \%)$, yang menjawab ragu-ragu 5 siswa (14,3\%) dan yang menjawab tidak setuju sebanyak 2 siswa $(5,7 \%)$.

Tabel 11 Siswa merasa tertantang untuk menyelesaikan cerita sampai tamat dengan menggunakan aplikasi Pixton

\begin{tabular}{|l|c|c|}
\hline \multicolumn{1}{|c|}{ JAWABAN } & FREKUENSI & PERSENTASE \\
\hline Sangat setuju & 17 & $48,6 \%$ \\
\hline Setuju & 11 & $31,4 \%$ \\
\hline Ragu-ragu & 4 & $11,4 \%$ \\
\hline Tidak setuju & 3 & $8,6 \%$ \\
\hline Sangat tidak setuju & - & - \\
\hline JUMLAH & 35 & $100 \%$ \\
\hline
\end{tabular}

Berdasarkan data tabel 11 di atas dapat diketahui bahwa responden yang menyatakan merasa tertantang untuk menyelesaikan cerita sampai tamat dengan menggunakan aplikasi Pixton. Yang menjawab sangat setuju sebanyak 17 siswa $(48,6 \%)$. Yang menjawab setuju sebanyak 11 siswa $(31,4 \%)$, yang menjawab ragu-ragu 4 siswa $(11,4 \%)$ dan yang menjawab tidak setuju sebanyak 3 siswa $(8,6 \%)$. 
Vol 2. No 1. Januari 2022 P-ISSN : 2774-8022, e-ISSN : 2774-5791

Tabel 12 Menulis cerita menggunakan aplikasi Pixton lebih menarik dari pada menulis cerita di selembar kertas.

\begin{tabular}{|l|c|c|}
\hline \multicolumn{1}{|c|}{ JAWABAN } & FREKUENSI & PERSENTASE \\
\hline Sangat setuju & 21 & $60 \%$ \\
\hline Setuju & 12 & $34,3 \%$ \\
\hline Ragu-ragu & 2 & $5,7 \%$ \\
\hline Tidak setuju & - & - \\
\hline Sangat tidak setuju & - & - \\
\hline JUMLAH & 35 & $100 \%$ \\
\hline
\end{tabular}

Berdasarkan data tabel 12 di atas dapat diketahui bahwa responden yang menyatakan menulis cerita menggunakan aplikasi Pixton lebih menarik dari pada menulis cerita di selembar kertas. Yang menjawab sangat setuju sebanyak 21 siswa (60\%). Yang menjawab setuju sebanyak 12 siswa $(34,3 \%)$, yang menjawab ragu-ragu 2 siswa $(5,7 \%)$.

Tabel 13 Ketika sudah menyelesaikan sebuah cerita di aplikasi Pixton, siswa berencana membuat cerita lagi

\begin{tabular}{|l|c|c|}
\hline \multicolumn{1}{|c|}{ JAWABAN } & FREKUENSI & PERSENTASE \\
\hline Sangat setuju & 17 & $48,6 \%$ \\
\hline Setuju & 4 & $11,4 \%$ \\
\hline Ragu-ragu & 13 & $37,1 \%$ \\
\hline Tidak setuju & 1 & $2,9 \%$ \\
\hline Sangat tidak setuju & - & - \\
\hline JUMLAH & 35 & $100 \%$ \\
\hline
\end{tabular}

Berdasarkan data tabel 13 di atas dapat diketahui bahwa responden yang menyatakan berencana membuat cerita lagi dengan menggunakan aplikasi Pixton. Yang menjawab sangat setuju sebanyak 17 siswa (48,6\%). Yang menjawab setuju sebanyak 4 siswa $(11,4 \%)$, yang menjawab ragu-ragu 13 siswa $(37,1 \%)$ dan yang menjawab tidak setuju sebanyak 1 siswa $(2,9 \%)$.

Tabel 14 Aplikasi Pixton dapat meningkatkan kreativitas siswa

\begin{tabular}{|l|c|c|}
\hline \multicolumn{1}{|c|}{ JAWABAN } & FREKUENSI & PERSENTASE \\
\hline Sangat setuju & 22 & $62,9 \%$ \\
\hline Setuju & 11 & $31,4 \%$ \\
\hline Ragu-ragu & 2 & $5,7 \%$ \\
\hline Tidak setuju & - & - \\
\hline Sangat tidak setuju & - & - \\
\hline JUMLAH & 35 & $100 \%$ \\
\hline
\end{tabular}


Vol 2. No 1. Januari 2022 P-ISSN : 2774-8022, e-ISSN : 2774-5791

Berdasarkan data tabel 14 di atas dapat diketahui bahwa responden yang menyatakan aplikasi Pixton dapat meningkatkan kreativitas siswa. Yang menjawab sangat setuju sebanyak 22 siswa $(62,9 \%)$. Yang menjawab setuju sebanyak 11 siswa $(31,4 \%)$, yang menjawab raguragu 2 siswa $(5,7 \%)$.

Tabel 15 Aplikasi Pixton dapat meningkatkan minat menulis cerita

\begin{tabular}{|l|c|c|}
\hline \multicolumn{1}{|c|}{ JAWABAN } & FREKUENSI & PERSENTASE \\
\hline Sangat setuju & 23 & $65,7 \%$ \\
\hline Setuju & 10 & $28,6 \%$ \\
\hline Ragu-ragu & 1 & $2,9 \%$ \\
\hline Tidak setuju & 1 & $2,9 \%$ \\
\hline Sangat tidak setuju & - & - \\
\hline JUMLAH & 35 & $100 \%$ \\
\hline
\end{tabular}

Berdasarkan data tabel 15 di atas dapat diketahui bahwa responden yang menyatakan aplikasi Pixton dapat meningkatkan minat menulis cerita. Yang menjawab sangat setuju sebanyak 23 siswa (65,7\%). Yang menjawab setuju sebanyak 10 siswa $(28,6 \%)$, yang menjawab ragu-ragu 1 siswa $(2,9 \%)$, dan yang menjawab tidak setuju 1 siswa $(2,9 \%)$.

\section{Hasil Menulis Cerita Melalui Aplikasi Pixton}

Hasil yang didapat dari tes akhir materi menyusun cerita dalam tabel 16 sebagai berikut. Ada lima peserta didik yang mendapatkan nilai 95. Sebelas peserta didik yang mendapatkan nilai 90. Tiga belas peserta didik yang mendapatkan nilai 80. Empat peserta didik yang mendapatkan nilai 75 . Dua peserta didik yang mendapatkan nilai 65 . Nilai rata-rata menyusun cerita dengan menggunakan aplikasi Pixton yaitu 83,8.

Tabel 16 Hasil tes akhir menulis cerita sesudah menggunaka aplikasi Pixton

\begin{tabular}{|c|c|c|}
\hline NO & JUMLAH SISWA & NILAI \\
\hline 1 & 5 & 95 \\
\hline 2 & 11 & 90 \\
\hline 3 & 13 & 80 \\
\hline 4 & 4 & 75 \\
\hline 5 & 2 & 65 \\
\hline & TOTAL 35 SISWA & RATA-RATA 83,8 \\
\hline
\end{tabular}


Hasil Tes Akhir Menulis Cerita sesudah menggunakan aplikasi Pixton

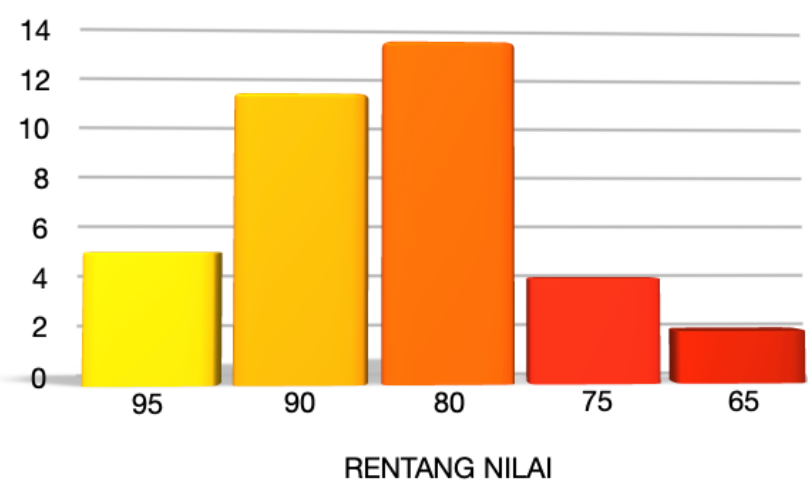

JUMLAH SISWA 35

Tabel 17 Hasil tes akhir menulis cerita sebelum menggunaka aplikasi Pixton

\begin{tabular}{|c|c|c|}
\hline NO & JUMLAH SISWA & NILAI \\
\hline 1 & 3 & 95 \\
\hline 2 & 4 & 90 \\
\hline 3 & 5 & 85 \\
\hline 4 & 4 & 80 \\
\hline 5 & 13 & 75 \\
\hline 6 & 3 & 70 \\
\hline 7 & 3 & 65 \\
\hline & TOTAL 35 SISWA & RATA-RATA 79 \\
\hline
\end{tabular}

Hasil Tes Akhir Menulis Cerita sebelum menggunakan aplikasi Pixton

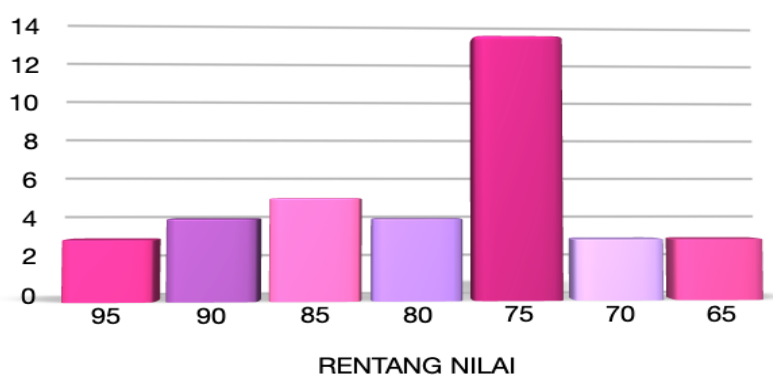

JUMLAH SISWA 35 


\section{Pembahasan}

\section{Tingkat Kemenarikan Aplikasi Pixton untuk Peningkatan Minat Menulis Cerita}

Dari data yang diperoleh melalui angket terhadap 35 responden menyatakan sudah pernah menulis cerita sebanyak 34 responden dan hanya 1 responden saja yang menyatakan ragu-ragu pernah menulis sebuah cerita pendek. Ini berarti responden sudah mendapatkan teori tentang cara menyusun sebuah cerita sebanyak $97 \%$.

Minat responden untuk menjadi penulis cerita terlihat dari jumlah pilihan sangat setuju dan setuju sejumlah 25 responden. Sedangkan yang ragu-ragu dan tidak setuju sejumlah 10 responden. Dari data tersebut menyatakan bahwa 71,4\% responden sudah memiliki minat untuk menjadi penulis cerita meskipun dalam lingkup sekolah.

Aplikasi Pixton merupakan hal baru bagi responden. Dari data angket sebanyak 17 responden atau 45,8\% menyatakan sudah pernah menggunakan aplikasi. Aplikasi Pixton merupakan aplikasi yang mudah digunakan meskipun bagi pemula. Hal ini dapat diketahui dari pilihan responden yang menyatakan sangat setuju dan setuju sebanyak $77,2 \%$. Responden yang menggunakan aplikasi ini tidak perlu pandai menggambar. Responden dapat mengembangkan daya imajinasinya dengan menuangkan ceritanya ke dalam sebuah gambar karena tersedia tool untuk menggambar (Hidayah, 2019).

Kemenarikan aplikasi Pixton bila digunakan untuk menulis cerita dapat dilihat dari jumlah responden yang menjawab sangat setuju dan setuju sebanyak 91,4\%. Ini mengindikasikan bahwa aplikasi ini bisa menjadi alat untuk menarik responden dalam menulis cerita. Aplikasi Pixton merupakan media yang dapat memberikan materi pembelajaran yang sangat menarik dengan pilihan gambar dan warna yang bermacam-macam (Kurniawan dkk, 2019).

Dari hasil penelitian yang dilakukan Kanti dkk (2018) menyatakan daya tarik media pembelajaran komik digital memperoleh respon yang sangat baik dari siswa, ditunjukkan dengan hasil angket respon siswa dengan hasil media pembelajaran komik digital sangat menarik. Pada uji coba yang dilakukan dalam penilaian daya tarik media pembelajaran komik digital diperoleh hasil uji kelompok kecil rata-rata skor angket respon siswa adalah $87 \%$ dan uji kelompok besar memperoleh rata-rata skor $88 \%$. Hal ini menunjukkan bahwa aplikasi Pixton sangat menarik digunakan dalam pembelajaran.

Aplikasi Pixton sangat mudah digunakan. Hal ini dapat dilihat dari jawaban responden yang menyatakan sangat setuju dan setuju sebanyak $80 \%$ bahwa penggunaan aplikasi tidak ditemukan kesulitan dalam mengoperasionalkannya. Responden merasa terbantu dengan aplikasi Pixton dalam menyelesaikan tugas menulis cerita. Hal ini dapat diketahui dari jumlah responden yang menjawab sangat setuju dan setuju sebanyak $88,6 \%$.

Dengan adanya aplikasi Pixton responden menyatakan dapat menyelesaikan sebuah cerita dengan pilihan jawaban sangat setuju dan setuju sebanyak $85,7 \%$. Penggunaan aplikasi Pixton ini dapat membantu responden dalam mengungkapkan ide-ide cerita. Hal ini dapat dilihat dari pilihan jawaban responden yang menyatakan sangat setuju dan setuju sebanyak 80\%. Aplikasi Pixton tidak membuat responden bosan dalam menyelesaikan sebuah cerita. Hal ini dapat diketahui dari jawaban responden yang menyatakan sangat setuju dan setuju sebanyak $80 \%$.

Responden merasa tertantang untuk menyelesaikan cerita sampai tamat dengan menggunakan aplikasi Pixton. Hal ini dapat diketahui dari jumlah responden yang menjawab sangat setuju dan setuju sebanyak $80 \%$. Menulis cerita dengan menggunakan aplikasi Pixton lebih menarik dari pada menulis cerita di selembar kertas. Potensi komik sebagai media dalam pendidikan pun selalu diakui oleh guru dan ahli psikologi. Penelitian dan eksperimen telah dilakukan dengan menggunakan komik dalam kelasnya (Farniella, 2018). Hal ini dapat diketahui dari jumlah responden yang menjawab sangat setuju dan setuju sebanyak 94,3\%. Responden berencana membuat cerita lagi ketika sudah menyelesaikan sebuah cerita di aplikasi Pixton. Jumlah responden yang sangat setuju dan setuju sebanyak 60\%.

Aplikasi Pixton dapat meningkatkan kreativitas. Sebanyak 94,3\% responden 
Vol 2. No 1. Januari 2022 P-ISSN : 2774-8022, e-ISSN : 2774-5791

menyatakan sangat setuju dan setuju dengan pernyataan ini. Aplikasi Pixton dapat meningkatkan minat menulis cerita. Terbukti dari jumlah pilihan jawaban yang menyatakan sangat setuju dan setuju sebanyak $94,3 \%$. Hal ini senada dengan pendapatnya Nurvianti dan Syarkowi (2018) menyatakan komik dapat digunakan sebagai bahan pembelajaran karena dinilai memberikan keefektifan dalam proses belajar mengajar, meningkatkan semangat dan keinginan untuk belajar peserta didik sehingga lebih mengerti serta menguasai konsep yang diajarkan.

\section{Hasil Menulis Cerita melalui Aplikasi Pixton}

Hasil yang didapat dari tes akhir materi menyusun cerita dapat diketahui 29 responden mendapatkan nilai di atas KKM. Nilai KKM yang ditentukan yaitu 77. Ketuntasan secara klasikal yakni $75 \%$. Nilai rata-rata menyusun teks cerita 83,8.

Hasil belajar mengalami peningkatan dikarenakan penggunaan media pembelajaran yang berdaya guna. Hal ini terlihat dari tercapainya tujuan pembelajaran dengan peningkatan aspek kognitif, psikomotorik dan afektif dalam proses pembelajaran (Daryanto, 2016). Dengan demikian, aplikasi Pixton dapat meningkatan minat menulis eerita.

\section{KESIMPULAN}

Dengan berbekal teori menulis cerita di kelas sebelumnya menjadi penentu kelancaran dalam menyusun cerita dengan menggunakan aplikasi Pixton ini. Dari awal pembelajaran terlihat bahwa responden memiliki minat untuk menjadi penulis cerita meskipun dalam lingkup sekolah.

Aplikasi Pixton merupakan hal baru bagi responden. Dengan memanfaatkan hal ini akan bisa menarik minat untuk menulis cerita yang selama ini dianggap sebagai hal yang sulit. Meskipun baru pertama kali menggunakan aplikasi ini ternyata responden tidak merasa kesulitan.

Aplikasi Pixton dianggap menarik karena karakter tokoh-tokohnya bisa dikreasikan sendiri dalam bentuk avatar. Mulai dari pemilihan bentuk wajah, tubuh, pakaian, assesoris dan lainnya. Ini mengindikasikan bahwa aplikasi ini bisa menjadi alat untuk menarik responden dalam menulis cerita.

Aplikasi Pixton sangat mudah digunakan. Responden merasa terbantu dengan aplikasi Pixton dalam menyelesaikan tugas menulis cerita. Penggunaan aplikasi Pixton ini dapat membantu responden dalam mengungkapkan ide-ide cerita. Aplikasi Pixton tidak membuat responden bosan dalam menyelesaikan sebuah cerita. Responden merasa tertantang untuk menyelesaikan cerita sampai tamat.

Menulis cerita dengan menggunakan aplikasi Pixton lebih menarik dari pada menulis cerita di selembar kertas. Responden berencana membuat cerita lagi ketika sudah menyelesaikan sebuah cerita di aplikasi Pixton. Selain itu, hasil nilai rata-rata menulis cerita yaitu 83,8. Dengan demikian, aplikasi Pixton dapat meningkatkan kreativitas dan meningkatkan minat menulis cerita.

\section{DAFTAR PUSTAKA}

Dalman. (2016). $\begin{gathered}\text { Keterampilan } \\ \text { https://books.google.co.id/books?id=3cdEAAAQBAJ\&printsec=frontcover\&dq=mac }\end{gathered}$
$\frac{\text { am+KETERAMPILAN+menulis\&hl=id\&newbks=1\&newbks_redir=0\&sa=X\&ved= }}{\text { 2ahUKEwi08dPr9rzAhVZAXIKHQL4CtsQ6AF6BAgGEAI\#v=onepage\&q=macam }}$
\%20KETERAMPILAN\%20menulis\&f=false

Farniella, Matteo.(2018). The Potential of Comics in Science Communication. Journalof Science Communication. Vol. 17, No. 01, pp. 1-17.

Freeman, Michelle S. (2020). Story Writing in the Accounting Classroom. The Accounting Educators' Journal. Vol XXX, pp. 67-86.

Hermawan, Ike Lendi. (2019). Pengembangan E-Comic menggunakan Pixton dan Kalase pada Materi Program Linear Dua Variabel Berbantuan Geogebra. Skripsi. UNEJ: Tidak 
diterbitkan.

https://repository.unej.ac.id/bitstream/handle/123456789/92423/Lendi\%20Ike\%20He rmawan\%20-\%20150210101015_.pdf?sequence=1\&isAllowed=y

Hidayah, Khilda Maulida. 2019. Pengembangan Media Komik Digital Menggunakan Pixton Disertai Quiz (Kahoot) pada Konsep Sistem Gerak. Skripsi. UIN Hidayatullah Jakarta: Tidak diterbitkan.

Jahja, Yudri. (2011). Psikologi Perkembangan. Jakarta:Kencana Prenada Media Group.

Jamhari, Muhammad, Siregar, Daulat. (2019). Pedoman Penulisan Karya Ilmiah untuk Siswa SMA.

From

https://books.google.co.id/books?id=OZIIEAAAQBAJ\&printsec $=$ frontcover $\& \mathrm{dq}=\mathrm{K}$ ETERAMPILAN+BERBAHASA+YANG+PALING+SULIT\&hl=id\&newbks=1\&n ewbks_redir $=0 \& s a=X \&$ redir_esc $=y \# v=$ onepage $\& \mathrm{q}=$ KETERAMPILAN\%20BERBA HASA \%20YANG\%20PALING\%20SULIT\&f=false

Kanti, Fitra Yurisma, Suyadi, Bambang, Hartanto, Wiwin. (2018). Pengembangan Media Pembelajaran Komik Digital pada Kompetensi Dasar Sistem Pembayaran dan Alat Pembayaran untuk Siswa Kelas X IPS di MAN 1 Jember. Jurnal Pendidikan Ekonomi: Jurnal Ilmiah Ilmu pendidikan, Ilmu Ekonomi, dan Ilmu Sosial. Vol 12 No 1, 135-141. Kurniawan, Dede Trie. Tresnawati, Nailah. Maryanti, Sri. (2019). Implementasi Aplikasi Pixton Sebagai Upaya Meningkatan Keterampilan Pembuatan Bahan Ajar Digital Dalam Bentuk Komik Untuk Mahasiswa Calon Guru Sekolah Dasar. Jurnal Ilmiah Pendidikan Dasar Vol 2 No 2, 71-83

Mastini, M., Suwandi, S., \& Sumarwati, S. (2016). Peningkatan Keterampilan Menulis Cerpen Melalui Metode Pembelajaran Berbasis Pengalaman dan Media Audiovisual pada Sekolah Menengah Pertama. Jurnal S2 Pendidikan Bahasa Indonesia, Vol 1 No 1, 2234.

Muallimin. (2019). Pengaruh Pengetahuan Teori dan Minat Menulis Cerita terhadap Kemampuan Menulis Cerita Siswa Kelas VIII SMP Negeri 3 Sengkang. Tesis. Pascasarjana Univ. Muhahhadiyah Makassar. https://digilibadmin.unismuh.ac.id/upload/12019-Full_Text.pdf

Munirah. (2015). Pengembangan Keterampilan Menulis Paragraf. From https://books.google.co.id/books?id=koSYDwAAQBAJ\&printsec $=$ frontcover\&dq=K ETERAMPILAN+menulis+cerita\&hl=id\&newbks=1\&newbks_redir=0\&sa=X\&redir _esc $=\mathrm{y} \# \mathrm{v}=$ onepage $\& \mathrm{q}=\mathrm{KETERAMPILAN} \% 20$ menulis\%20cerita $\& \mathrm{f}=$ false

Nurvianti, I, Astalini dan A. Syarkowi. (2018). Penggunaan Media Komik pada Pembelajaran Fluida Statis di Kelas XI IPA SMA Negeri 2 Kota Jambi Tahun 2017. Jurnal Penelitian Pembelajaran Fisika, Vol. 9, No. 1. h. 2.

Padmi, Jatuh. (2017). Peningkatan Kemampuan Menulis Cerita Pendek melalui Pendekatan Kontekstual pada Siswa SMP Kelas VII. Jurnal Pendidikan Vol. 2, No 1, 21-28.

Setiawan, Andik. (2021). Ayo Menulis Cerpen Pelajar Penggugah Jiwa. From https://books.google.co.id/books?id=r2M0EAAAQBAJ\&printsec $=$ frontcover $\& \mathrm{dq}=\mathrm{m}$ inat+menulis+cerita\&hl=id\&newbks=1\&newbks_redir $=0 \& s a=X \&$ redir_esc $=y \# v=$ on epage \&q\& $\mathrm{f}=$ false

Simarmata, Janner. (2019). Kita Menulis: Semua Bisa Menulis Buku. From https://books.google.co.id/books?id=UdjFDwAAQBAJ\&printsec=frontcover\&dq=ra gam + menulis\&hl=id\&newbks $=1 \&$ newbks_redir=0\&sa $=X \&$ redir_esc $=y \# v=$ onepage $\& \mathrm{q}=$ ragam $\% 20$ menulis $\& \mathrm{f}=$ false

Sudjiono, Anas.2004. Pengantar Statistik Pendidikan. Jakarta: Raja Grafindo Persada.

Sumardjo, Jacob. 2007. Catatan Kecil tentang Menulis Cerpen. Yogyakarta: Pustaka Pelajar.

Sumirah. (2009). Peningkatan Minat dan Keterampilan Menulis Cerita dengan Media Gambar Berseri pada Siswa Kelas $V$ SDN Plosolor 02 Karangjati Ngawi Tahun 2008/2009. Tesis. Universitas Sebelas Maret Program Pascasarja Surakarta: Tidak diterbitkan. 


\section{Vol 2. No 1. Januari 2022 P-ISSN : 2774-8022, e-ISSN : 2774-5791}

Sutrisno. (2021). Meningkatkan Minat dan Hasil Belajar TiIK Materi Topologi Jaringan Dengan Media Pembelajaran.

From https://books.google.co.id/books?id=v1UNEAAAQBAJ\&pg=PA10\&dq=pengertian + minat\&hl=id\&newbks $=1 \&$ newbks_redir $=0 \& s a=X \& v e d=2 a h U K E w j M m K \_b 2 N r z A$ hUOOisKHV7BCzMQ6AF6BAgEEAI\#v=onepage $\& \mathrm{q}=$ pengertian $\% 20$ minat $\& \mathrm{f}=$ fals e

Wahyuni, Sri. (2018). Peningkatan Kemampuan Menulis Cerpen Siswa Kelas IX.2 SMP Negeri 3 Batanghari dengan Menggunakan Media Noveltoon Semester I Tahun Ajaran 2018/2019. Journal Education of Batanghari. Vol. 2, No. 8, 103-115. 